\title{
Influence of diversified relief on the urban heat island in the city of Kraków, Poland
}

\author{
Anita Bokwa $^{1}$ • Monika J. Hajto ${ }^{2} \cdot$ Jakub P. Walawender $^{1,2} \cdot$ Mariusz Szymanowski $^{3}$
}

Received: 14 October 2014 / Accepted: 20 July 2015 / Published online: 15 August 2015

(C) The Author(s) 2015. This article is published with open access at Springerlink.com

\begin{abstract}
In cities located in concave landforms, urban heat island (UHI) is an element of a complicated thermal structure and occurs due to the common impact of urban built-up areas and orography-induced processes like katabatic flows or air temperature inversions. Kraków, Poland (760,000 inhabitants) is located in a large valley of the river Vistula. In the years 2009-2013, air temperature was measured with the 5-min sampling resolution at 21 urban and rural points, located in various landforms. Cluster analysis was used to process data for the night-time. Sodar and synoptic data analysis provided results included in the definition of the four types of nighttime thermal structure representing the highest and the lowest spatial air temperature variability and two transitional types. In all the types, there are three permanent elements which show the formation of the inversion layer, the cold air reservoir and the UHI peak zone. As the impact of land use and relief on air temperature cannot be separated, a concept of relief-modified UHI (RMUHI) was proposed as an alternative to the traditional UHI approach. It consists of two steps: (1) recognition of the areal thermal structure taking into consideration the city centre as a reference point and (2) calculation of RMUHI intensity separately for each vertical zone.
\end{abstract}

Anita Bokwa

anita.bokwa@uj.edu.pl

1 Institute of Geography and Spatial Management, Jagiellonian University, 7 Gronostajowa St., Kraków, Poland

2 Centre for Hydrological and Meteorological Measurement Service, Satellite Remote Sensing Department, Institute of Meteorology and Water Management - National Research Institute, 14 Borowego St., Kraków, Poland

3 Institute of Geography and Regional Development, University of Wrocław, 1 Uniwersytecki Sq., 50-137 Wrocław, Poland

\section{Introduction}

The concept of urban heat island (UHI) has been well known since the nineteenth century; however, numerous methodological issues are still the subject of discussion. It is widely accepted that UHI, i.e. the occurrence of higher air temperature in urbanized areas than in rural areas, is the effect of combined influences mainly of changes to the surface geometry in the built environment due to land use changes and emission of anthropogenic heat. Lowry (1977) claimed that the value of a meteorological element measured in a city consists of three components: general climatic background, impact of local conditions (e.g. landform and land cover) and impact of urban areas. One of the local conditions is the impact of the relief on air temperature in the local scale. Goldreich $(1984,2009)$ summarized studies on that topic and stated that particular authors neglected the relief impact or included it only in a qualitative dimension. Other approaches comprised either elimination of the landform impact with the use of statistical procedures or emphasized the role of relief in a study as an important factor controlling the local climate. Unfortunately, the last option has not been popular so far. Good examples of the comprehensive approach are Nkemdirim (1980), Kuttler et al. (1996) and Suomi and Kayhko (2012), who studied the impact and spatial range of katabatic flows in cities of various sizes, located in mountainous valleys (Calgary, Stolberg, Turku, respectively). Besides, UHI formation and intensity in cities located in the mountains were studied, e.g. in Switzerland by Roten et al. (1984; for Fribourg) and Wanner and Hertig (1984; for Basle, Biel, Berne), in Austria by Lazar and Podesser (1999; for Graz) and Rupnik (2003; for Salzburg) or in Slovenia by Hocevar and Petkovsek (1995; for Ljubljana). Saaroni and Ziv (2010) analysed long-term changes in UHI intensity in Beersheba, Israel, and took into account the impact of topographic parameters on permanent 
factors controlling the phenomenon. Ketterer and Matzarakis (2014) studied the bioclimate of Stuttgart in relation to UHI and stressed the possible combined impact of orography and land use on the spatial variability of the urban microclimate.

As shown by Stewart $(2011 \mathrm{a}, \mathrm{b})$ for example, the popular use of $\Delta T_{\mathrm{u}-\mathrm{r}}$ (i.e. air temperature difference between an urban and a rural station) to define and quantify the UHI magnitude is weakening the philosophical and methodological integrity of the literature. A solution proposed by that author is the application of a local climate zones (LCZs) scheme. Stewart also described criteria which have to be considered to ensure reliable results of UHI studies. One of them is the diversified relief, a factor forcing, for example, the occurrence of processes like katabatic flows or cold air lake formation. Stewart and Oke (2012) suggested paying special attention to such factors which exert a combined effect with the LCZs, and to include them in the quantitative analysis.

The main research problem of this paper is rooted in the concept developed by Lowry (1977), mentioned above, who distinguished three components affecting air temperature in urban areas: general climatic background, local conditions (including relief) and impact of urban areas. In cities located in large valleys, like Kraków, urban areas and surrounding rural areas are located in various landforms (e.g. valley floor, slopes, hilltops). Additionally, in terms of population, Kraków is a much larger city than most of the settlements already mentioned above where the studies on UHI influenced by relief impact were conducted (e.g. Stolberg 60, 000; Turku 175,000; Fribourg 50,000; Graz 226,000; Salzburg 143,000; Ljubljana 300,000 inhabitants in the year of publication). Therefore, the aim of the present paper is an attempt to first separate the impact of two factors distinguished by Lowry (relief and land use/land cover) on air temperature, in a local scale (the third factor mentioned by Lowry, i.e. general climatic background, was considered to be uniform for the whole study area). Then, UHI intensity was determined, unbiased by the impact of relief, for various parts of the city located in different vertical zones. Land use/land cover features were defined using various indices. The LCZ scheme does not include the relief impact; therefore, it was used only in the initial phase of data analyses. First, the paper shows the mean air temperature as well as spatial and temporal variability for selected weather conditions, in order to highlight the basic methodological problems regarding the application of the classic UHI concept for a city located in a complex relief area. Then, alternative approaches to the estimation of UHI in urban areas of diversified relief are presented and the concept of relief-modified urban heat island (RMUHI) is introduced.

\section{Study area}

Kraków (Cracow) is a city in southern Poland, on the river Vistula, with an area of $326.8 \mathrm{~km}^{2}$ and about 760,000 permanent registered inhabitants (the total number is estimated to reach one million) (Fig. 1). The city is located in a concave landform, i.e. in the river valley passing from west to east. The historical city centre is placed on the bottom of the river Vistula valley (at about $200 \mathrm{~m}$ a.s.1.), on a limestone tectonic horst (Wawel Hill), emerging from the river valley. To the north of the river Vistula and the city centre is the KrakówCzęstochowa Upland, built of limestone and marls, and its parts located close to Kraków reach up to $300 \mathrm{~m}$ a.s.l. The southern borders of the city run partially in the Carpathian Foothills, built of Flysch rocks, with an elevation up to $370 \mathrm{~m}$ a.s.1. in the area neighbouring Kraków. The river Vistula valley is narrow in the western part of Kraków (about $1 \mathrm{~km}$ ) and widens to about $10 \mathrm{~km}$ in the eastern part. In the western part of the valley, there are several limestone tectonic horsts, reaching about $350 \mathrm{~m}$ a.s.1., so the city area is not surrounded by hills only from the east. The urbanized areas can be found in the river valley with its terraces and in convex landforms to the south and north of the city centre. Height differences between the valley floor and the hilltops next to the city borders are about $100 \mathrm{~m}$, and the built-up areas do not reach those hilltops.

Data on land use/land cover (LULC) structure are presented using modified GMES European Urban Atlas classes (GMES 2010; see Table 1). Within the city borders, built-up areas (classes 1-6) cover $43.0 \%$ of the area, while agricultural and semi-natural areas (class 8 ) amount to $41.3 \%$, and the remaining (green and water) areas cover $15.7 \%$ (Fig. 1c).

In the valley floor, many different land use types can be distinguished, while in the convex landforms south and north of the valley, only a few land use types can be found.

Due to the historical development of the city since the early Middle Ages, buildings with more than four storeys are located mainly in the suburbs, and those are districts with blocks of flats. Areas with compact built-up districts are found mainly in the old town. In the eastern part of the city, in the river valley bottom, is the Nowa Huta district with a huge steelworks, constructed after the Second World War. Originally, the city occupied only Wawel Hill and its close vicinity; then, it gradually expanded to the river valley floor, but further expansion to the convex landforms north and south of the city centre took place as late as the second half of the twentieth century and that process is still ongoing (Mydel 1996; Zborowski 2005). The local climate of Kraków has been studied by many researchers since the 1960 s, mainly in the context of air pollution dispersion conditions which are very poor, especially in comparison to other large Polish cities, e.g. Łódź, Warsaw or Wrocław (Fortuniak and Kłysik 2008; Błażejczyk et al. 2014; Szymanowski 2004), and have contributed to high pollution 


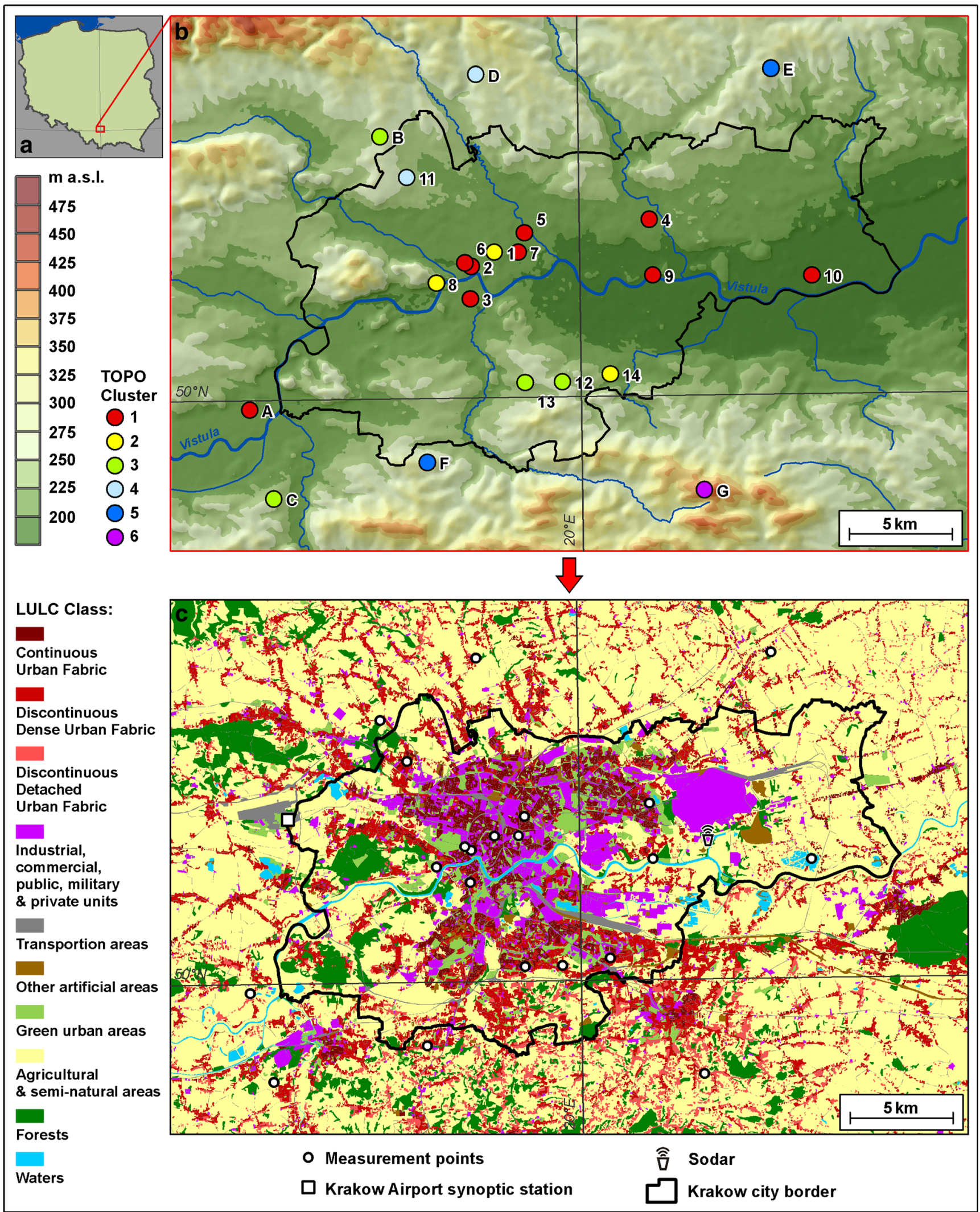

Fig. 1 Location of the study area (a), location and division of the measurement points into clusters according to the topographic parameters (b) and land use/land cover classes in the study area (c). Symbols of measurement points in $\mathbf{b}$ as in Table 2; LULC classes in $\mathbf{c}$ as in Table 1 
Table 1 Land use/land cover structure in Kraków (reclassified on the basis of GMES European Urban Atlas, GMES 2010)

\begin{tabular}{clcc}
\hline Class & Item & Total area $\left(\mathrm{km}^{2}\right)$ & Share (\%) \\
\hline 1 & Continuous urban fabric & 27.0 & 8.3 \\
2 & Discontinuous dense urban fabric & 36.3 & 11.1 \\
3 & Discontinuous detached urban fabric & 5.8 & 1.8 \\
4 & Industrial, commercial, public, military and private units & 44.5 & 13.6 \\
5 & Transportation areas & 19.2 & 5.9 \\
6 & Other artificial areas & 7.5 & 2.3 \\
7 & Green urban areas & 24.1 & 7.3 \\
8 & Agricultural and semi-natural areas & 134.9 & 41.3 \\
9 & Forests & 21.0 & 6.4 \\
10 & Waters & 6.5 & 2.0 \\
& Kraków & 326.8 & 100.0 \\
\hline
\end{tabular}

GMES European Urban Atlas classes included in the classes used in Table 1: class 1: 11100; class 2: 11210; class 3: 11220, 11230 and 11300; class 4: 12100; class 5: 12210, 12220, 12230 and 12400; class 6: 13100, 13300 and 13400; class 7: 14100 and 14200; class 8: 20000; class 9: 30000; class 10: 50000. Data source: GMES European Urban Atlas PL003L v.1.1 (available on-line at: http://www.eea.europa.eu/data-andmaps/data/urban-atlas) concentrations. The location in the valley running from the west to the east is the reason for significant modification in the wind direction frequency; winds from the western direction have the frequency of $21 \%$, while winds from the east make up $12 \%$ (Hess 1974). The natural ventilation of the city is limited due to the location in a semi-basin, and additionally, air temperature inversions are often formed. Atmospheric calms are as frequent as $27 \%$ (Hess 1974). The inversions frequently last for $24 \mathrm{~h}$ or more, especially in winter. Among numerous studies, Lewińska et al. (1982) published the results of a 3-year project (1975-1978) aimed at evaluating the spatial distribution of the main mesoclimate characteristics in Kraków. UHI magnitude was estimated to reach $2 \mathrm{~K}$, and it was determined as the minimum air temperature difference between the city centre and a rural measurement point, both located in the valley floor, as at that time many contemporary built-up areas located elsewhere did not exist. Air temperature inversions were studied in Kraków using various techniques, but the most complete information was obtained using sodar. Results of the multi-annual sodar measurements, which have been conducted in Kraków since 1980 by the Institute of Meteorology and Water Management, can be found in publications by Walczewski and Feleksy-Bielak (1988) and Walczewski (1989, 1994), for example, and the outcomes show that on average during over $60 \%$ of nights of the year, ground air temperature inversions were observed.

\section{Data and methods}

The present study is based on the following reasoning. In the studies on UHI, it is essential to obtain measurements which show air temperature differences due to land use/land cover modifications induced by processes of urbanization. In Kraków, however, relief is an important local climate factor, in spite of relatively small height differences in the study area, as it forces, for example, the formation of a cold air lake in the valley floor and air temperature inversions. Therefore, air temperature differences within the city and in rural areas around the city are formed in different parts of the valley due to various factors. Consequently, UHI is only a part of the spatial thermal mosaic, modified by the local climate factors.

\subsection{Location of measurement points}

Following the assumptions mentioned above, a network of 21 permanent measurement points was established in the area of Kraków and its vicinity (Fig. 1), in the years 2007-2009. The measurements were designed so as to obtain information on screen-level temperatures, and they have been performed according to the recommendations of Oke (2004). The locations of the measurement points were chosen to represent three vertical zones: the valley floor, an area $50 \mathrm{~m}$ above the valley floor (separately on the northern and southern slopes) and hilltops (about $100 \mathrm{~m}$ above the river valley bottom, separately on the northern and southern sides of the valley). One rural point was established in each of the first two vertical zones; for the hilltops, two rural points on each side of the valley ( $\mathrm{N}$ and $\mathrm{S}$ ) were organized, and in the case of urban points, their number in particular zones depended on the number of land use types to be found there. Additionally, the division of the city into western and eastern parts, i.e. narrow and wide parts of the valley, was carried out. 


\subsection{Land use/land cover and relief characteristics}

The following urban land use types were distinguished: blocks of flats, residential built-up areas, compact built-up areas (with street canyons), urban green areas and water bodies (Bokwa 2010). The network was organized before the first publications of the LCZ scheme (e.g. Stewart 2009, Stewart and Oke 2009), but the scheme (Stewart 2011a, Stewart and Oke 2012) is included in the description of measurement points, so as to improve further analyses or comparisons (Table 2). However, in some areas of the study area, spatial variability of LULC can be observed, due to gradual changes in the area functions in the last few centuries. Therefore, in case of some measurement points, two dominating LCZs were suggested. The source area was defined as the 500-m buffer around each point. For the buffered areas, land use and relief characteristics were extracted. The percentage share of different land use types within the $500-\mathrm{m}$ radius of each point was calculated on the basis of the European Urban Atlas (GMES 2010). For each point, the sky view factor (SVF) was estimated using fish-eye photos, processed with BMSky-view software (Rzepa and Gromek 2009; Bokwa 2010). The measurement point locations were chosen so as to be representative in terms of SVF values for the majority of the surrounding area. Other parameters included in the LCZ classification were estimated from in situ observations (aspect ratio, building height) or accepted as given in Stewart 2011a.

The second group of source-area characteristics was derived on the basis of a 30-m-resolution digital elevation model (DEM) of the study area. It consists of a few common and specific DEM derivatives:

- Absolute height.

- Relative height, calculated using an "Altitude above channel network" tool implemented in SAGA GIS software (http://www.saga-gis.org/en/index.html).

- Topographic position index (TPI; http://www.jennessent. com/arcview/tpi.htm), describing topographic position (concave/convex, slope, flat) of each point in the study area. For the purpose of this paper two horizontal ranges were taken into consideration for the calculations: 500 and $2000 \mathrm{~m}$ from each point.

- General slope inclination (SLP) calculated for 1-kmresolution DEM (resampled from the original 30-m DEM).

All indices described above were calculated for each measurement point in order to characterize the relief features in detail. Cluster analysis using the Ward method (Everitt et al. 2001) was used to group the points, each of them characterized with the values of the indices mentioned. Cluster analysis was also used in the further procedure. The division into topographic clusters obtained is shown in Fig. 1b. Six clusters can be distinguished. Cluster 1 contains points A, 2, 3, 4, 5, 6, 7,9 and 10 , all of them located in the valley floor, with relative height from 1 to $4 \mathrm{~m}$, negative values of TPI for the 2-km buffer and SLP below 0.4 . In cluster 2 , there are points 1,8 and 14 located in the valley floor and $50 \mathrm{~m}$ above it and their common feature is TPI for the 2-km buffer reaching values of 4-5. Cluster 3 consists of points B, C, 12 and 13, with TPI values for the 2-km buffer from 3 to 12 and all located about $50 \mathrm{~m}$ above the valley floor. Cluster 4 is composed of two points, 11 and $\mathrm{D}$, located in the northern part of the study area, 50 and $70 \mathrm{~m}$ above the valley floor, respectively; both have negative TPI values and much higher SLP values $(>1)$ than other points, as in the regional scale they are located on the huge slope of the Kraków-Częstochowa Upland. In cluster 5, there are points $\mathrm{E}$ and $\mathrm{F}$, i.e. two hilltops, and cluster 6 includes only one point, $\mathrm{G}$, at the highest location. For points $\mathrm{E}$, $\mathrm{F}$ and $\mathrm{G}$, the TPI values for the 2-km buffer are the highest, from 26 to 67 . The division shows that some measurement points which belong to a certain vertical zone (valley floor, slope, hilltop) have specific relief features, e.g. point $G$ is located about $100 \mathrm{~m}$ higher than other hilltop points and therefore is included in a separate cluster, and point 1 is located about $10 \mathrm{~m}$ higher than most other points in the valley floor, which is the reason for its exclusion from cluster 1 . The land use/land cover features and landform features were used further in the air temperature data interpretation as the LCZ scheme alone could not be used.

Table 2 presents the main topographic and land use/land cover parameters of the measurement points shown in Fig. 1.

\subsection{Measurement data}

Each measurement point has been equipped with an air temperature data logger. In 16 points, $\mathrm{HOBO}$ data loggers have been operating $\left(\mathrm{HOBO}^{\circledR}\right.$ PRO series Temp Data Logger, Onset Computer Corporation, Pocasset, MA, USA; operating range $T,-30$ to $50{ }^{\circ} \mathrm{C}$; resolution, $0.2{ }^{\circ} \mathrm{C}$ between 0 and $40{ }^{\circ} \mathrm{C}$ ), and in five points, those have been MINIKIN data loggers (EMS Brno, Czech Republic, operating range $T,-30$ to $60{ }^{\circ} \mathrm{C}$; accuracy $0.2{ }^{\circ} \mathrm{C}$ between 0 and $40{ }^{\circ} \mathrm{C}$ ); all of them were supplied with naturally ventilated solar radiation shields. The loggers were located 2-4 $\mathrm{m}$ above the ground, depending on the local conditions and safety demands. Air temperature values were recorded every $5 \mathrm{~min}$.

The data used come from 308 nights in the period September 2009-August 2013. The night-time was defined as the time span starting $2 \mathrm{~h}$ before sunset and lasting for $5 \mathrm{~h}$ after sunset. Therefore, we have taken into consideration only the first phases of UHI development, i.e. from its formation to stabilization. According to other studies (e.g. Oke 1987; Hage 1972; Camilloni and Barrucand 2012; Erell and Williamson 2007, Holmer et al. 2007; Linden 2011; Bohnenstengel et al. 2011), maximum UHI intensity is observed around $3-5 \mathrm{~h}$ after 
Table 2 Land use/land cover and topographic characteristics of the measurement points used in the study

\begin{tabular}{|c|c|c|c|c|c|c|}
\hline \multicolumn{2}{|c|}{ Measurement points } & \multirow{2}{*}{$\begin{array}{l}\text { Altitude } \\
\text { [m a.s.l.] }\end{array}$} & \multirow{2}{*}{ SVF } & \multirow{2}{*}{$\begin{array}{l}\text { Land } \\
\text { use type }\end{array}$} & \multirow{2}{*}{ LULC classes $^{\mathrm{b}}$} & \multirow{2}{*}{$\mathrm{LCZ}^{\mathrm{c}}$} \\
\hline Symbol $^{\mathrm{a}}$ & Name & & & & & \\
\hline \multicolumn{7}{|c|}{ Valley floor } \\
\hline A & Jeziorzany & 211 & 0.956 & $\begin{array}{l}\text { Rural } \\
\text { areas }\end{array}$ & & $\mathrm{D}$ \\
\hline 1 & $\begin{array}{l}\text { Słowackiego } \\
\text { Theatre }\end{array}$ & 215 & 0.695 & $\begin{array}{l}\text { Compact } \\
\text { built-up } \\
\text { (with } \\
\text { street } \\
\text { canyons) }\end{array}$ & & 2 \\
\hline 2 & $\begin{array}{c}\text { Krasińskiego } \\
\text { St. }\end{array}$ & 204 & 0.457 & $\begin{array}{l}\text { Compact } \\
\text { built-up } \\
\text { (with } \\
\text { street } \\
\text { canyons) }\end{array}$ & & 2 \\
\hline 3 & $\begin{array}{l}\text { Podwawelskie } \\
\text { district }\end{array}$ & 203 & 0.605 & $\begin{array}{l}\text { Blocks of } \\
\text { flats }\end{array}$ & & $4 / 5$ \\
\hline 4 & Szkolne district & 205 & 0.695 & $\begin{array}{l}\text { Blocks of } \\
\text { flats }\end{array}$ & & 5 \\
\hline 5 & Bema St. & 208 & 0.822 & $\begin{array}{l}\text { Residential } \\
\text { built-up }\end{array}$ & & $6 / 9$ \\
\hline 6 & $\begin{array}{c}\text { Błonia } \\
\text { meadows }\end{array}$ & 203 & 0.711 & $\begin{array}{l}\text { Urban } \\
\text { green } \\
\text { areas }\end{array}$ & & $\mathrm{D} / \mathrm{B} / 2$ \\
\hline 7 & $\begin{array}{c}\text { Botanical } \\
\text { Garden }\end{array}$ & 206 & 0.690 & $\begin{array}{l}\text { Urban } \\
\text { green } \\
\text { areas }\end{array}$ & & $\mathrm{B} / 2$ \\
\hline 8 & $\begin{array}{c}\text { Malczewskiego } \\
\text { St. }\end{array}$ & 222 & 0.788 & $\begin{array}{l}\text { Urban } \\
\text { green } \\
\text { areas }\end{array}$ & & $\mathrm{B} / \mathrm{D}$ \\
\hline 9 & Wandy bridge & 197 & 0.939 & $\begin{array}{l}\text { Water } \\
\text { bodies }\end{array}$ & & G/D \\
\hline 10 & $\begin{array}{l}\text { Przylasek } \\
\text { Rusiecki }\end{array}$ & 190 & 0.690 & $\begin{array}{l}\text { Water } \\
\text { bodies }\end{array}$ & & $\mathrm{G} / \mathrm{B}$ \\
\hline & & h slope & $\mathrm{m}$ abo & the valley & & \\
\hline
\end{tabular}

sunset although there are also studies which show that the maximum intensity can be observed just before sunrise (e.g. Jauregui et al. 1992; Fortuniak and Kłysik 1998). Preliminary analysis of the data used in the present study showed that within the time span of $5 \mathrm{~h}$ after sunset, the maximum air temperature differences in the study area are most often observed. During the selected nights, after sunset, cloudiness did not exceed 4 oktas and the wind speed was below $4 \mathrm{~m} \mathrm{~s}^{-1}$, according to the meteorological data from the Kraków Airport synoptic station located in Balice about $11 \mathrm{~km}$ west of the city centre (241 m a.s.l.; Fig. 1). For the nights chosen, the complete measurement data were available from at least 19 points (for 174 nights, the data were available for 21 measurement points; for another 76 nights, for 20 points; and for another 58 nights, for 19 points).

The results obtained were interpreted using additional meteorological data (from the Kraków Airport synoptic station) and sodar data. The sodar data were used in the study as they 
Table 2 (continued)

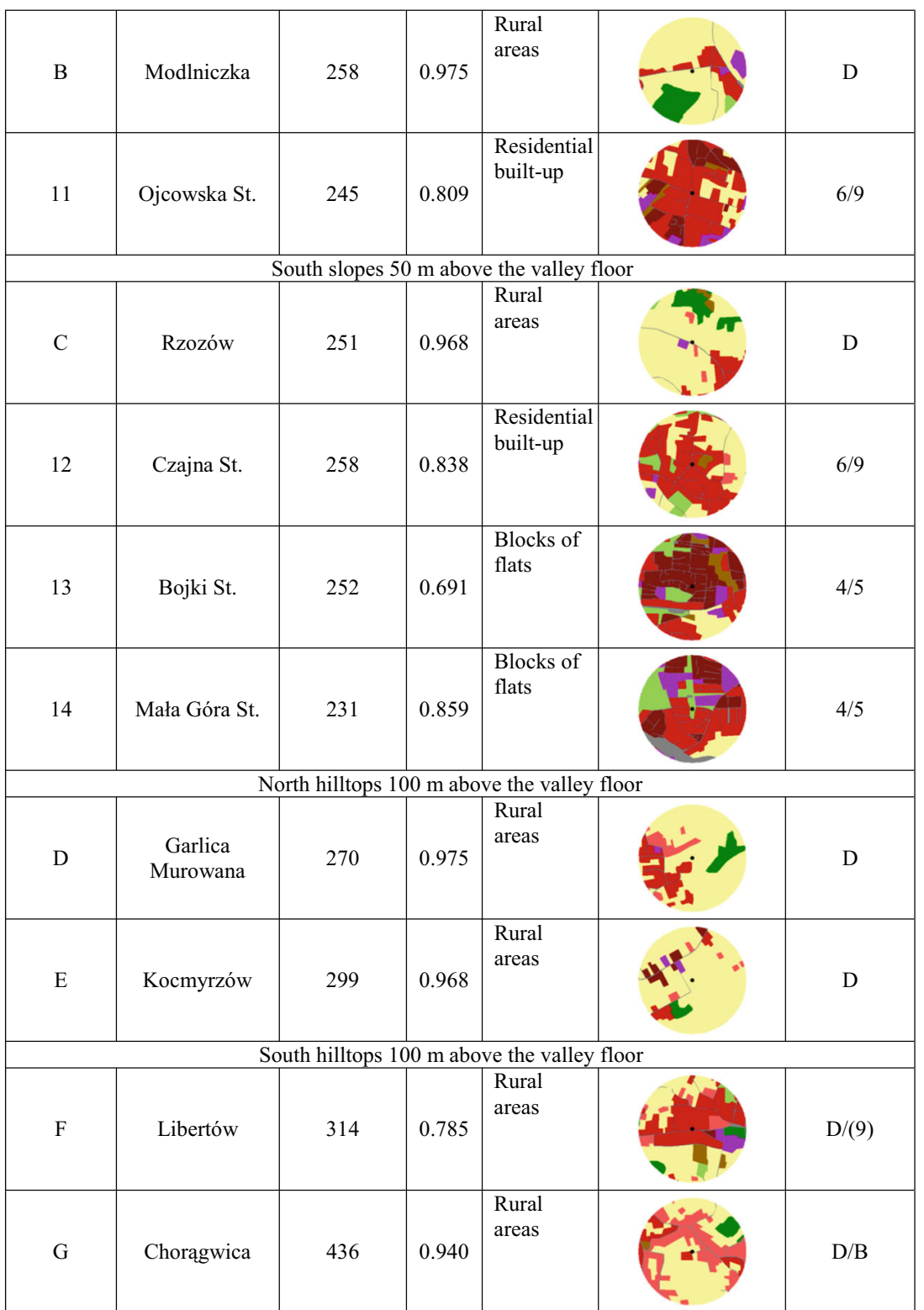

${ }^{\text {a }}$ Symbols like in Fig. 1: numbers 1, 2, 3, etc. indicate urban measurement points; letters A, B, C, etc. indicate rural measurement points

${ }^{\mathrm{b}}$ In the areas of 500-m radius around each measurement point, legend of LULC classes like in Fig. 1 and Tab. 1

${ }^{\mathrm{c}}$ According to Stewart $(2011 \mathrm{a}, \mathrm{b})$

allow information to be obtained about air temperature inversions, an important phenomenon controlling the local climate of Kraków. The present sodar measurement station has worked continuously since May 2010 and is located in the eastern part of the city, in the Nowa Huta district, close to the steelworks (198 m a.s.l.; Fig. 1c).

Sodar equipment which provided the acoustic soundings data was developed in the Institute of Meteorology and Water Management, Kraków Branch (Walczewski 1989). The latest model of a sounder, called the vertical Doppler sodar, has been working with a few breaks from 1994 until now. A sodar loudspeaker emits every $6 \mathrm{~s}$ a $0.8-\mathrm{kW}$ sound pulse of $1.6-\mathrm{kHz}$ frequency lasting $60 \mathrm{~ms}$. The loudspeaker is also a microphone which receives an acoustic backscatter signal (echo). Subsequently, the amplified echo is recorded and imaged as an echogram. The range of the sodar echo is $1 \mathrm{~km}$. Sodar echograms are analysed manually and visually. Such analysis enables determination of thermal convection vertical structures and horizontal structures of air temperature inversion layers (ground-based or elevated). Their heights are normally determined as 
hourly averages. A schematic diagram of the sodar system and an example of a 24-h echogram is presented by Zimnoch et al. (2010).

In the present study, the sodar data from the period May 2010-August 2013 were used. In the whole period, sodar data were available for 216 nights (i.e. $70 \%$ of the 308 nights originally selected for analysis), and in particular for 105 nights when air temperature data were available for 21 measurement points, for 74 nights when air temperature data were available for 20 points and 37 nights when air temperature data were available for 19 points. As the sodar measurements were not available for the whole study period, they could only be used for some additional analyses.

\subsection{Methods of data analysis}

The data gathered were used first to recognize the basic features of the spatial variability of air temperature during the night-time in the study area. The mean night-time air temperature course was calculated for each point, for all nights. The courses were grouped using cluster analysis (Ward method). The results obtained allowed the reference point for further analysis to be chosen. Then, night-time air temperature spatial patterns and temporal phases were established. Air temperature differences between the reference point and all other points were calculated for each night considered. Next, for each night, a sequence of the difference courses was composed, using always the same order of stations. All the nights were grouped using cluster analysis with the $k$-means method in order to obtain types of spatial and temporal structure of air temperature differences in the study area. For each cluster (structure type), mean courses of air temperature differences were calculated for each point. Next, hourly averages of the differences were computed and then the averages from selected 1-h intervals were mapped to present spatially and temporally the structure types distinguished. The final outcomes allowed proposals to be formulated concerning UHI and its intensity definitions for cities located in areas with complex relief. Application of particular methods allowed to obtain results which determined next steps of analysis; therefore, further details concerning methods are provided in Section 4.

\section{Results}

\subsection{Night-time air temperature spatial patterns}

Many studies on UHI showed that urban and rural areas not only have different air temperatures during the night-time, but they also differ significantly in the air temperature courses during the night (e.g. Ketzler et al. 2006). Therefore, in the first step, for each measurement point, the mean night-time air temperature course was calculated, using data for 174 nights (i.e. data from all points were available). In particular, 12 nights occurred in winter (Dec.-Feb.), 40 nights in spring (Mar.-May), 78 nights in summer (Jun.-Aug.) and 44 nights in autumn (Sep.-Nov.). The mean air temperature courses were grouped with the Ward method (Fig. 2) in order to see whether the land use/land cover features, characteristic for urban and rural points, respectively, turn out to be decisive in controlling the night-time air temperature changes, as is the case of flat areas.

The decision on how many clusters should be finally distinguished is always subjective, even though there are formulas which can be used in the initial phase of analysis to estimate the number of clusters which are significantly different from one another. The application of objective methods used to determine the number of clusters, developed by e.g. Stanisz and Grabiński or Mojena (after Panek 2009), allows only two clusters to be obtained, i.e. the cluster tree should be cut at the binding distance 40 . However, such a division seems to be too coarse as the first cluster is composed of urban points located in the valley floor (numbers 1, 2, 3, 4, 5, 7) and urban points representing areas with blocks of flats at the slopes $(13,14)$, but three rural points located at the hilltops $(\mathrm{E}, \mathrm{F}, \mathrm{G})$ are included, too. The second cluster is composed of rural points located in the valley floor and on the slopes (A, B, C, D), urban points with residential built-up areas on the slopes (11, $12)$ and green/water areas in the valley floor $(6,8,9,10)$. That division shows that the air temperature in the study area is controlled by various factors which influence particular sites with different intensities. In the first cluster, points with the most intensive built-up areas are grouped, regardless of the landform, but three rural stations at the hilltops are included as well. In the second cluster, points with no built-up or sparse built-up areas can be found, located in the valley floor or on the slopes. In order to study better in the further analyses the combined impact of the land use and the landform, the division into six clusters is proposed. The objects grouped in the

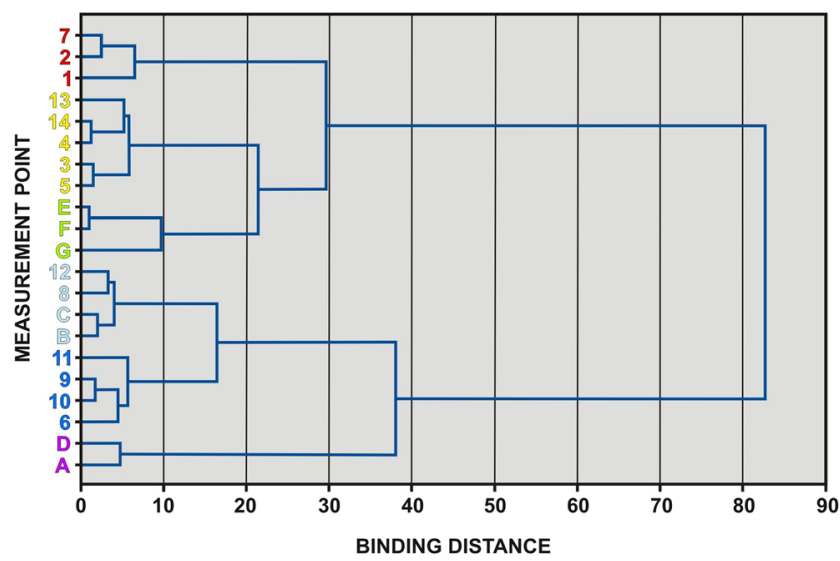

Fig. 2 Cluster analysis result for mean nocturnal air temperature courses at the measurement points in Kraków and its vicinities, for selected nights in the period 2009-2013. Colours of the clusters' numbers correspond to colours used in Fig. 3 
analysis were mean nocturnal air temperature courses, calculated for the data from only chosen nights, with little or no cloudiness and weak or no wind. It means the data showed mean conditions during an air temperature inversion situation. In such situation, the rural points at the hilltops are often above the inversion layer and therefore, the air temperature there is higher than in other rural points located lower. In fact, sometimes, it is not much lower than in the urban area in the valley floor. However, the reason why the temperature is relatively high in urban areas in the valley floor is the effect of urban structures, and the reason why the temperature is also relatively high at the hilltops is relief-related factor (i.e. location above the inversion layer). The urban areas on the slopes are at the same time urban areas at the suburbs, and in those areas, sometimes, the land use/land cover factors are dominant, and sometimes those are relief-dependent factors. Those differences can be seen in the division into six clusters.

Figure 3 shows the spatial distribution of each cluster member.

In order to use the data presented above to study UHI, first, the answer to the following question has to be found: how is the UHI intensity defined and calculated? In the classic approach, the reference point is usually a rural location with the lowest values of air temperature. However, the analysis of the values in mean night-time air temperature courses, presented above, showed that there are large differences in thermal conditions among the rural sites around Kraków, as they are influenced by various processes linked, for example, to the inversion layer formation; there is not just one rural station representative for the whole non-urban area. The first step towards the definition of UHI in such circumstances was then the recognition of the thermal structure of the study area, using air temperature differences, where the reference point was the one where the air temperature values are always the highest, i.e. measurement point 1 (Slowackiego Theatre), located in the valley floor, in the city centre. Table 3 shows the main features of particular clusters.

The cluster analysis presented above shows that some characteristic features of UHI can be seen but they are modified probably by the processes linked to the relief impact. In the city centre, located in the valley bottom, which is the area with the most compact built-up areas, the mean night-time air temperature is the highest, so it has been assigned to the "peak" zone in the UHI scheme (cluster 1). Worth mentioning is the exclusion of point 6 from cluster 1, as it is a vast, flat, open green area of $48 \mathrm{ha}$, and even though it is located close to the city centre, the air temperature was much lower there than at nearby urban points. The "plateau" zone of UHI is not as uniform as the classic UHI pattern. Cluster 2 represents areas where mean night-time air temperature is about $1 \mathrm{~K}$ lower than in the peak zone, with blocks of flats located in two vertical zones and residential built-up areas, but only those

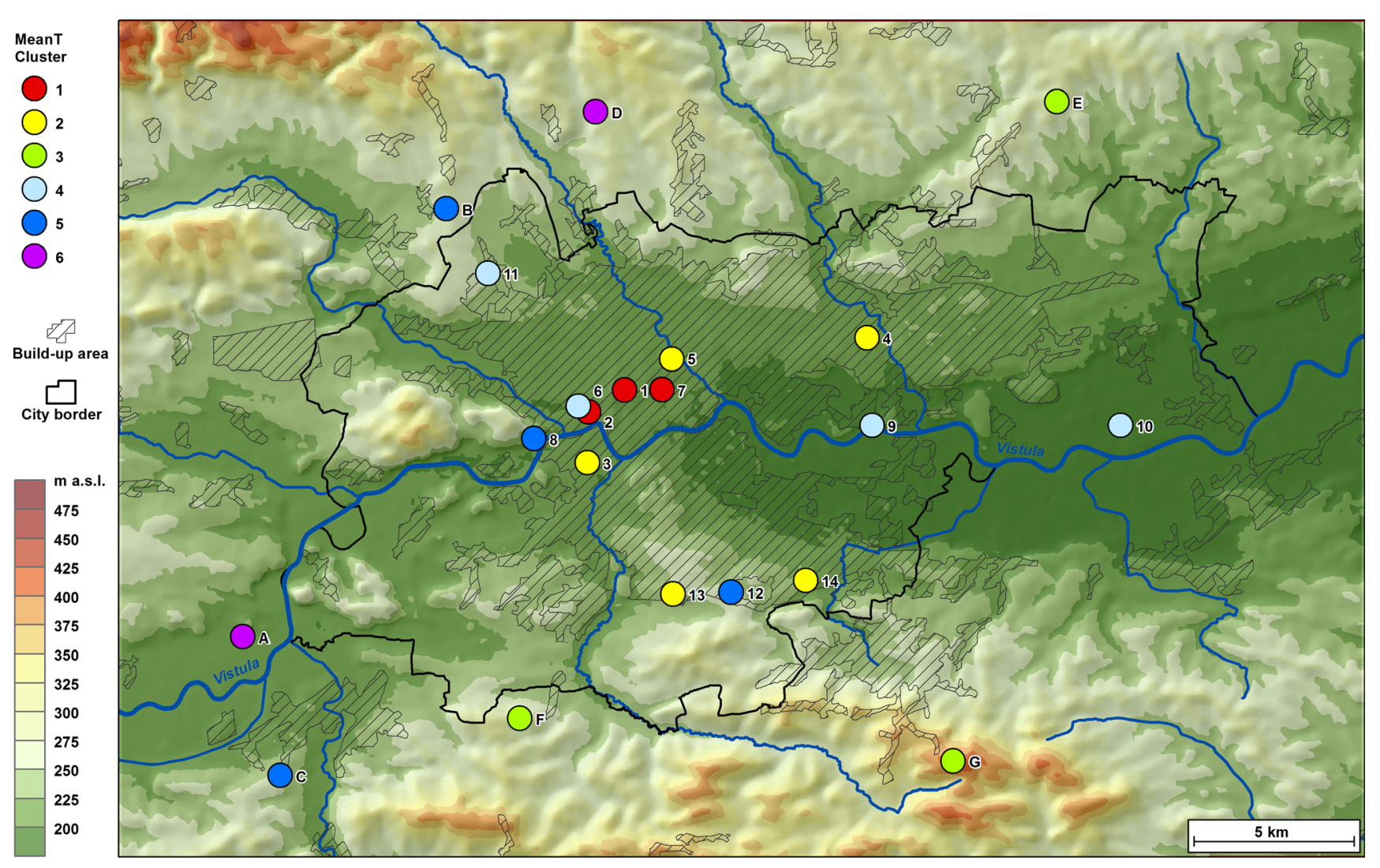

Fig. 3 Spatial distribution of measurement points belonging to particular clusters shown in Fig. 2 
Table 3 Mean air temperature differences at the night-time between point no. 1 and other points (mean dT), standard deviation for the averaged night-time air temperature difference course (SD) and the difference between the highest and the lowest values in the averaged night-time air temperature difference course $(\Delta \mathrm{dT})$, in particular measurement points belonging to the clusters distinguished

\begin{tabular}{|c|c|c|c|c|}
\hline \multicolumn{2}{|c|}{ Measurement points } & \multirow[t]{2}{*}{ Mean dT } & \multirow[t]{2}{*}{ SD } & \multirow[t]{2}{*}{$\Delta \mathrm{d}$} \\
\hline Symbol & Name & & & \\
\hline \multicolumn{5}{|c|}{ Cluster 1} \\
\hline 2 & Krasińskiego St. & 0.2 & 0.4 & 1.3 \\
\hline 7 & Botanical Garden & 0.4 & 0.6 & 1.5 \\
\hline \multicolumn{5}{|c|}{ Cluster 2} \\
\hline 3 & Podwawelskie district & 1.1 & 0.7 & 2.1 \\
\hline 4 & Szkolne district & 1.3 & 0.4 & 1.2 \\
\hline 5 & Bema St. & 1.0 & 0.7 & 2.3 \\
\hline 13 & Bojki St. & 0.9 & 0.3 & 0.9 \\
\hline 14 & Mała Góra St. & 1.3 & 0.4 & 1.3 \\
\hline \multicolumn{5}{|c|}{ Cluster 3} \\
\hline $\mathrm{E}$ & Kocmyrzów & 1.2 & 0.5 & 1.6 \\
\hline $\mathrm{F}$ & Libertów & 1.2 & 0.5 & 1.6 \\
\hline G & Choragwica & 1.9 & 0.7 & 2.5 \\
\hline \multicolumn{5}{|c|}{ Cluster 4} \\
\hline 6 & Błonia & 1.6 & 1.0 & 2.7 \\
\hline 9 & Wandy Bridge & 1.6 & 0.8 & 2.2 \\
\hline 10 & Przylasek Rusiecki & 1.7 & 0.7 & 2.1 \\
\hline 11 & Ojcowska St. & 2.0 & 1.1 & 3.4 \\
\hline \multicolumn{5}{|c|}{ Cluster 5} \\
\hline 8 & Malczewskiego St. & 2.5 & 0.8 & 2.8 \\
\hline 12 & Czajna St. & 2.3 & 0.8 & 2.6 \\
\hline B & Modlniczka & 2.4 & 1.0 & 3.1 \\
\hline $\mathrm{C}$ & Rzozów & 2.2 & 1.0 & 3.1 \\
\hline \multicolumn{5}{|c|}{ Cluster 6} \\
\hline A & Jeziorzany & 3.3 & 1.8 & 5.2 \\
\hline $\mathrm{D}$ & Garlica Murowana & 3.7 & 1.5 & 4.5 \\
\hline
\end{tabular}

Symbols as in Fig. 1

located in the valley floor. However, similar mean temperatures are found in rural areas located often above the inversion layer, on the southern and north-eastern hilltops (points E and F; cluster 3), with the exception of point $\mathrm{G}$, placed much higher and influenced by the mesoregional air temperature pattern. Residential built-up areas located on the slopes (points 11 and 12) were grouped either together with urban green areas located in the valley floor (cluster 4; point 11) or with rural points on the slopes (cluster 5; point 12). Such a division shows that air temperature in areas with residential built-up districts is more diversified within the city than the temperature in areas with blocks of flats. While areas with blocks of flats show similar thermal conditions, regardless of the vertical zone, areas with residential built-up districts located on the slopes have significantly lower air temperature than areas with the same land use but located in the valley floor. Rural points were included in three clusters, i.e. cluster 6 representing areas with the lowest night-time air temperature in the whole study area, located in the valley bottom (so-called cold air lake) and on the north-western hilltop (points A and D, respectively), and in clusters 3 and 5 , as mentioned above. That pattern is an indication of frequent air temperature inversions and high heterogeneity in the pattern of night-time air temperature spatial distribution. An interesting feature of the pattern described is the inclusion of point $\mathrm{D}$, located about $70 \mathrm{~m}$ above the valley floor, in the same cluster as point A, located in the valley floor, in the extent of the cold air lake. The area located north of the river Vistula, in the western part of the valley, belongs to a large landform, i.e. the southern slope of the Jurassic KrakówCzestochowa Upland. The slope consists of huge steps and is cut with deep valleys. Katabatic flows can develop there on a much larger area and can have larger intensity than in the areas located to the south of the river Vistula. Therefore, the cold air accumulation can occur not only in the valley floor but also on some slopes and even lower hilltops in the northern part of the study area.

The results presented above show some spatial features of the air temperature pattern in Kraków and its vicinity. The next step towards the modified UHI definition was the recognition of temporal phases in the air temperature difference courses at particular points, which are described in the next section.

\subsection{Night-time air temperature structure types}

In order to recognize the temporal phases in the air temperature difference courses in the study area, the following procedure was used. The differences between measurement point 1 and the other points were used. Point 1 was used as a reference point following the results presented in the previous section. For each night, the air temperature difference courses were arranged into one numerical sequence, always following the same order of stations. The $k$-means method of cluster analysis was used to group nights, each of them defined with such a set of air temperature difference courses. That procedure was repeated three times, for the datasets containing air temperature records from 21, 20 and 19 measurement points. For each dataset, the analysis was conducted for the assumptions of 3 , 4 and 5 clusters distinguished. For further analyses, the division into four clusters was chosen. The four groups of mean air temperature difference courses for particular points represent four types of spatial and temporal structure of air temperature difference during the night-time in Kraków and its vicinity. Data for 21 measurement points were taken for further processing in order to present the most complete dataset; the results obtained were very similar to those for 20 or 19 points. Figure 4 presents mean courses of air temperature differences for particular points calculated for the clusters (structure types) distinguished. Figure 5 shows hourly averages of air 

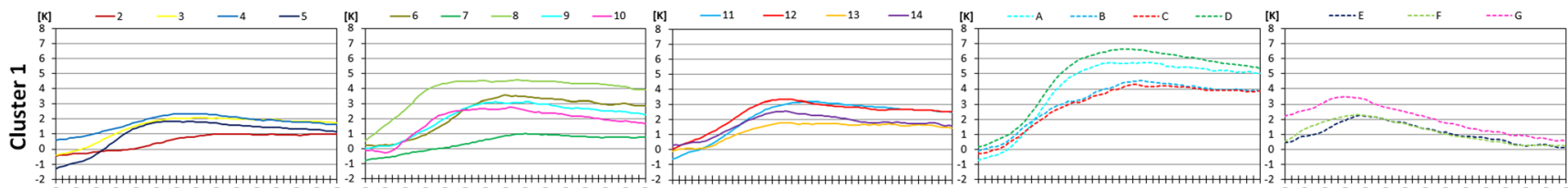

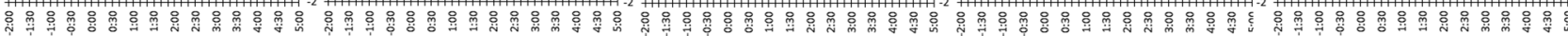
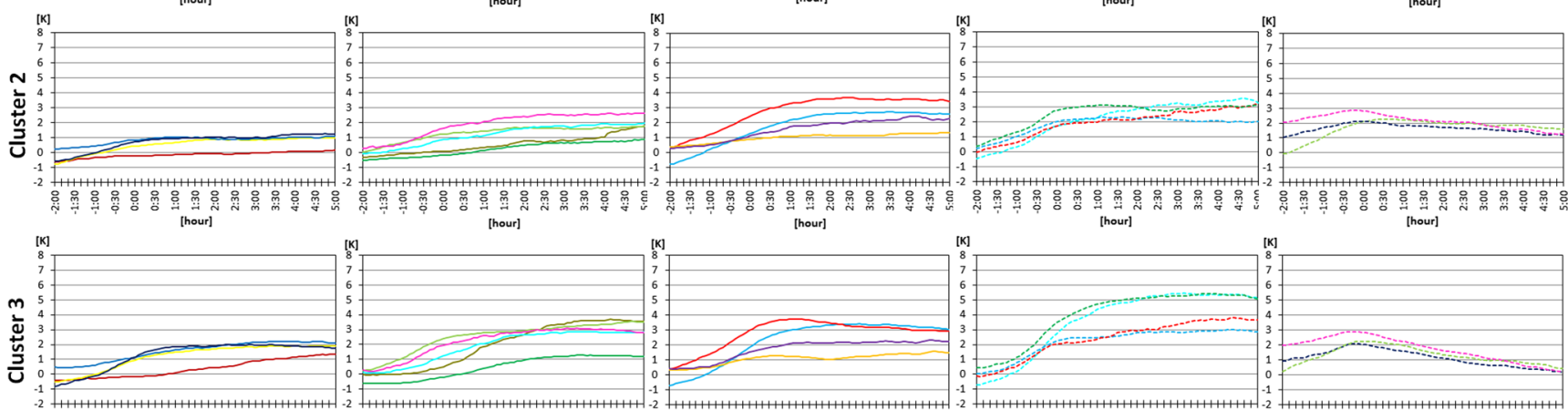

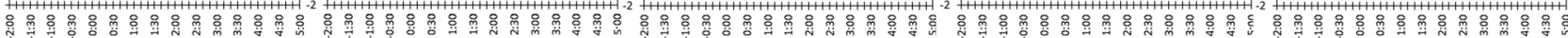
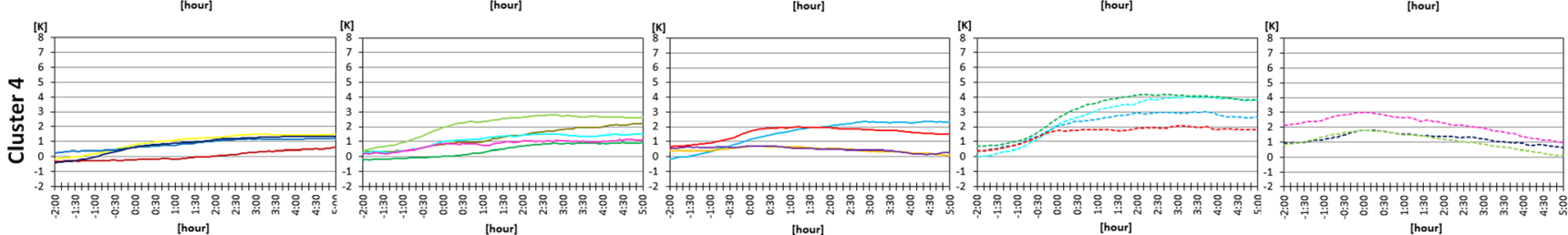

Fig. 4 Mean courses of air temperature differences (in relation to reference point 1) for the clusters distinguished

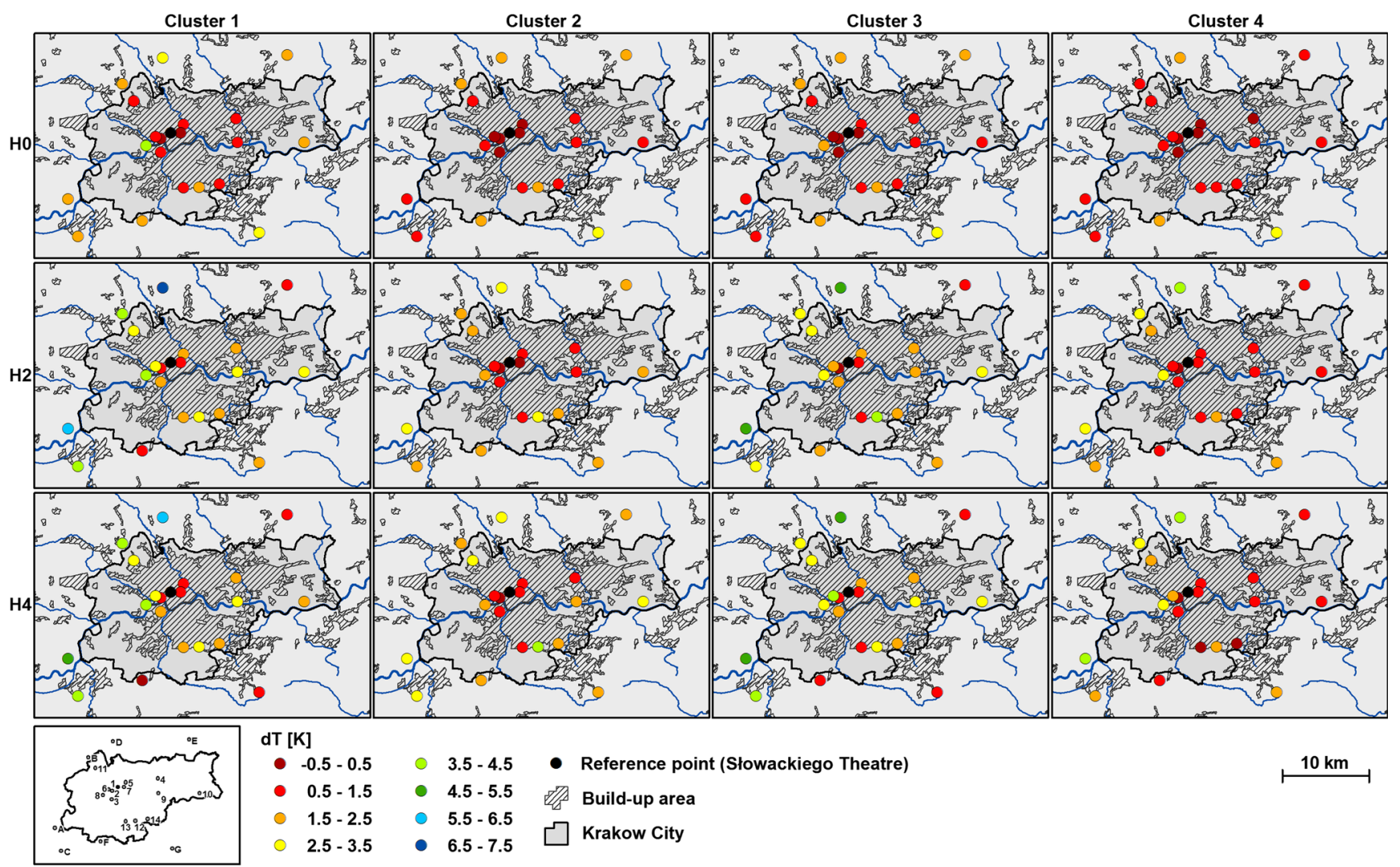

Fig. 5 Hourly averages of air temperature differences at particular measurement points from three selected 1-h intervals (H0, H2, H4) for the clusters distinguished. $H O$ interval between hours -1 and 0 (with sunset as hour 0 ), $H 2$ interval between hours 1 and 2, $H 4$ interval between hours 3 and 4 
temperature differences from three selected 1-h intervals (H0, $\mathrm{H} 2$ and $\mathrm{H} 4$ ) for the clusters (structure types) distinguished, at particular measurement points. Data presented in Fig. 5 show the gradual development of the spatial pattern of differences with respect to the four structures distinguished during the night-time, and the last time interval (H4) is taken further to characterize the classic UHI elements.

For the four clusters (structure types), accompanying atmospheric conditions and the air temperature inversion layer were analysed. Figure 6 shows mean hourly values of cloudiness, wind speed, air temperature and relative humidity, observed in the Kraków Airport synoptic station, while Fig. 7 shows the frequency of wind directions for particular clusters and hours. Mean hourly height and frequency of the air temperature inversion layer, derived from the sodar data, for particular clusters are presented in Fig. 8. The long-term sodar measurements conducted in Kraków (from the 1980s) confirmed that the air temperature inversion layer in Kraków can occur at wind speeds up to $4 \mathrm{~m} \mathrm{~s}^{-1}$, most probably due to the location of the city in the valley.

The final four types of spatial and temporal air temperature difference structures can be described as follows:

1. Structure type (cluster) 1 -with the highest values (Fig. 4) and the most intensive changes (Fig. 5) in air temperature differences between the reference point and the other points. The mean air temperature decrease in the synoptic station within the 7-h night-time was the largest (about $11 \mathrm{~K}$ ), and the mean air temperatures were the largest, too $\left(14-24{ }^{\circ} \mathrm{C}\right)$ (Fig. 6). In this structure type, hourly averages of air temperature differences (dT) for the measurement points vary spatially the most compared to other distinguished clusters (Fig. 5). In the fourth hour after sunset $(\mathrm{H} 4)$, averaged air temperature at point $\mathrm{F}$ is similar to the value at point 1 ; for points 2,5 and 7 as well as $\mathrm{E}$ and $\mathrm{G}, \mathrm{dT}$ is around $1 \mathrm{~K}$; for points $3,4,10,13$ and 14 it is about $2 \mathrm{~K}$; for points $6,9,11$ and 12 around $3 \mathrm{~K}$; for points $8, \mathrm{~B}$ and $\mathrm{C}$ about $4 \mathrm{~K}$; and for points $\mathrm{A}$ and $\mathrm{D}$ about 5 and $6 \mathrm{~K}$, respectively. This structure type occurred when the mean cloudiness and wind speed after sunset were the lowest on average, compared to the nights classified to other structures (i.e. less than 1 okta and less than $1 \mathrm{~m} \mathrm{~s}^{-1}$, respectively). The type occurred almost exclusively during summer months; of 46 nights included in that cluster, 40 belonged to the period June-August. Additionally, atmospheric calms prevailed (about $45 \%$ for each hour after sunset; Fig. 7). Those results show first of all the formation of the inversion layer (data for points E, F, G where after sunset the differences diminish to reach values close to 0 at the end of the night-time). The inversion layer after sunset was the lowest compared to other clusters (between 140 and $180 \mathrm{~m}$ a.g.1.; Fig. 8). The UHI peak zone seems to be limited to the city centre (point 1 and about $1 \mathrm{~K}$ lower temperature at points 2, 5 and 7). The plateau zone of UHI is dispersed and includes areas with blocks of flats and residential built-up areas, located in the valley floor and on the slopes (points 3, 4, 13 and 14). Further use of the classic UHI concept is problematic, especially in the spatial aspect. At the same time when the air temperature at rural hilltops is almost the same as in the city centre in the valley floor, the highest difference values, up to 6-7 K, occur in the western rural part of the valley floor (point A) and on the slopes on the lower hilltops (point D) in the northern part of the study area during the whole time after sunset, due to the formation of the cold air lake and katabatic flow, respectively. An interesting feature is that the temperature difference at point $\mathrm{D}$, located in northern hilltops, about
Fig. 6 Mean hourly values of cloudiness (a), wind speed (b), air temperature (c) and relative humidity (d) for particular air temperature structure types, according to the data from Kraków Airport synoptic station
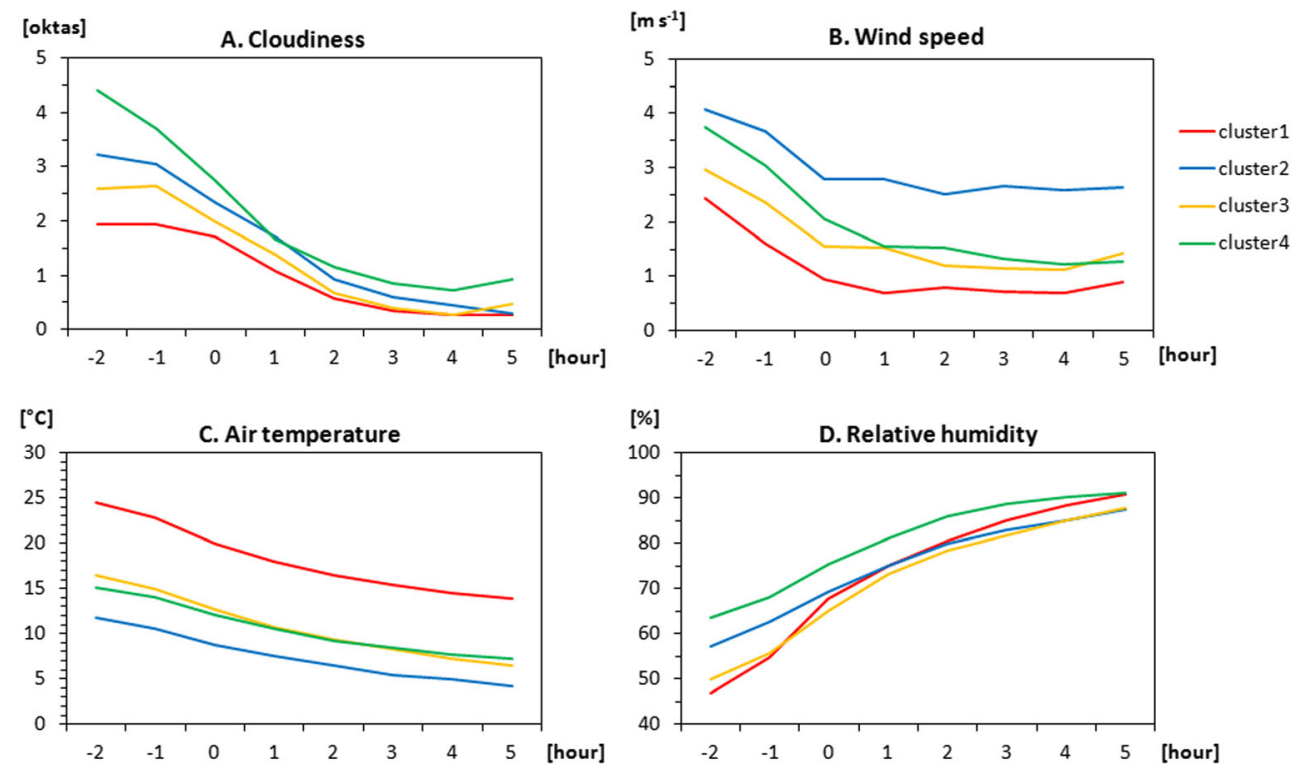
Fig. 7 Frequency of wind directions for particular air temperature structure types and hours, according to the data from Kraków Airport synoptic station
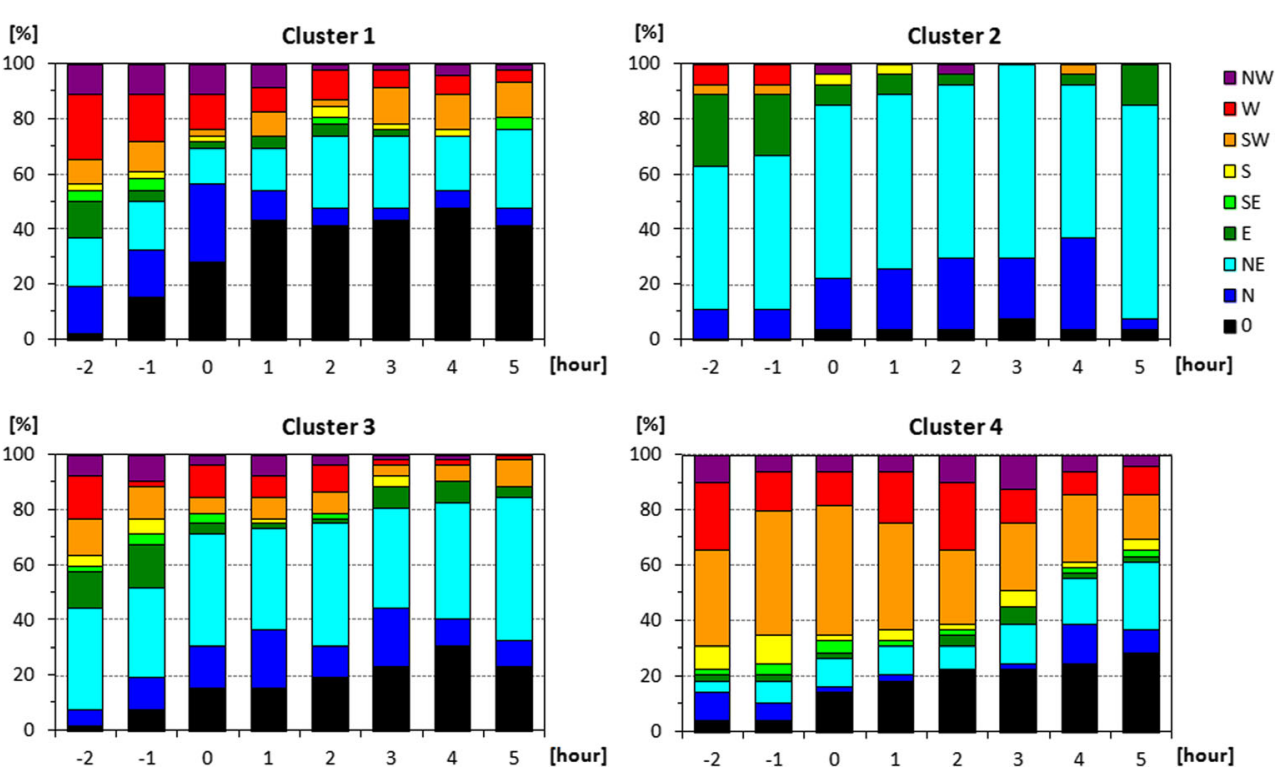

$70 \mathrm{~m}$ above the valley floor, is about $6 \mathrm{~K}$, while for point $\mathrm{E}$, located also in northern hilltops but about $100 \mathrm{~m}$ above the valley floor, it reaches only about $1 \mathrm{~K}$. The relief of the study area shows asymmetry in both N-S and W-E crosssections. Point D is placed in the western, narrow (about $1 \mathrm{~km}$ ) part of the river valley (in W-E cross-section) while point $\mathrm{E}$ in the eastern, much wider (about $10 \mathrm{~km}$ ) part of the valley. Additionally, in the north of point $\mathrm{D}$, there are areas of increasing altitude, in regional scale, as point $\mathrm{D}$ is in the marginal zone of the Kraków-Częstochowa Upland. Point E, instead, is placed on an extensive plateau. Therefore, at the area where point D is located, katabatic flows are detected indirectly, while various
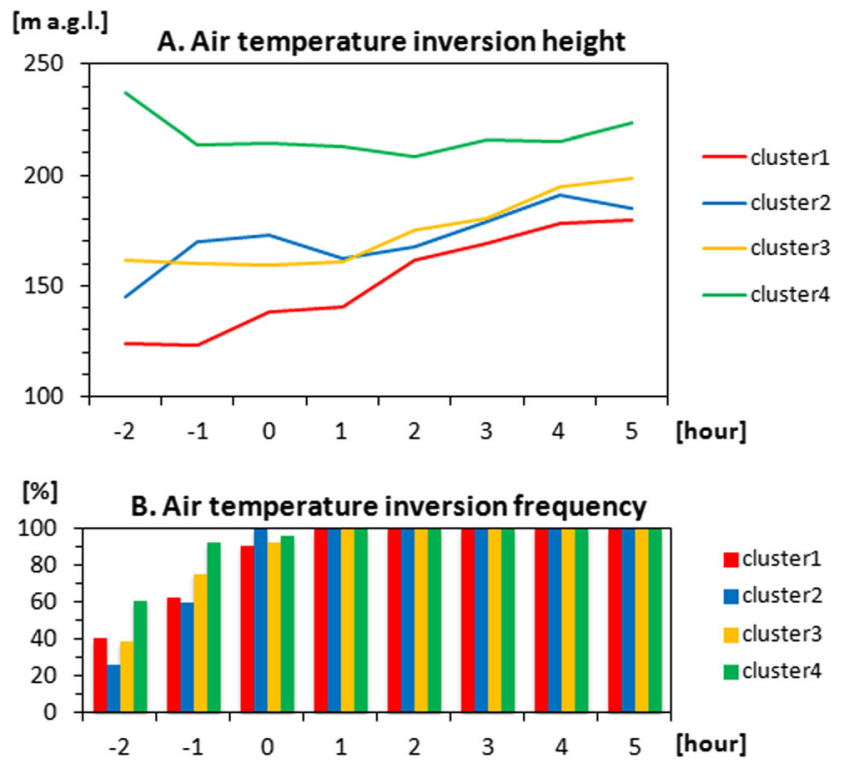

Fig. 8 Mean hourly height (a) and frequency (b) of air temperature inversion layer for particular air temperature structure types, derived from the sodar data observations from the area where point $\mathrm{E}$ is placed show no such phenomena (Bokwa 2010). In areas with residential built-up districts located $50 \mathrm{~m}$ above the valley floor (points 11 and 12), the air temperature differences are similar to those in urban green areas and at the water areas in the valley bottom (points 6,9 and 10), maximum difference values reach about $3 \mathrm{~K}$, while in rural areas located $50 \mathrm{~m}$ above the valley floor (points B and C) as well as other green urban areas located in the valley bottom (point 8 ), they increase to $4 \mathrm{~K}$ most of the night-time.

2. Structure type (cluster) 2-with the lowest values (Fig. 4) and the least intensive changes (Fig. 5) in air temperature differences between the reference point and the other points. The mean air temperature decrease in the synoptic station is the smallest (about $7 \mathrm{~K}$ ) and so are the air temperatures: $4-12{ }^{\circ} \mathrm{C}$, compared to other types (Fig. 6). In this structure type, hourly averages of air temperature differences (dT) for the measurement points are the least spatially varied compared to other distinguished clusters (Fig. 5). Four hours after sunset (H4), averaged air temperature at point 2 is similar to the value at point 1 ; for points $3,4,5,6,7$ and 13 , dT is around $1 \mathrm{~K}$; for points 8,9 and 14 as well as B, E, F and G, it is about $2 \mathrm{~K}$; for points $10,11, \mathrm{~A}, \mathrm{C}$ and $\mathrm{D}$ around $3 \mathrm{~K}$; and point 12 is about $4 \mathrm{~K}$ colder than point 1 . This structure type occurs when the mean cloudiness after sunset is similar to that of type 1 (less than 1 okta), but the mean wind speed after sunset is the largest, compared to the nights classified to other types (clusters), i.e. about $2.5 \mathrm{~m} \mathrm{~s}^{-1}$. The prevailing wind direction is NE (Fig. 7). The type occurred mainly from autumn to spring; of 27 nights included in this cluster, 21 belonged to the period September-April. The results indicate that in structure type 2 , the UHI peak zone is more extended than in structure 1 and includes points $1,2,3,4$, 
$5,6,7$ and 13 , i.e. areas with various urban built-up districts located in the valley floor. The plateau zone includes urban green and water areas, located in the river valley (points $8,9,10$ ). Like in the case of structure type 1, the development of the inversion layer and cold air reservoir can be traced, taking into consideration data from Fig. 4, but the dT values indicate lower intensity of the process. The mean height of the inversion layer after sunset is similar as in case of structure type 1 (between 160 and $190 \mathrm{~m}$ a.g.l.; Fig. 8). Urban areas located on the slopes cannot be easily included in any classic UHI zone.

3. Structure type (cluster) 3-together with type 4, it presents the transitional type of structure, between the patterns with the highest and the lowest air temperature difference values (Figs. 4 and 5). In this structure type, hourly averages of air temperature differences (dT) for the measurement points were less spatially varied than in structure type 1 but more than in structure type 2 (Fig. 5). In the fourth hour after sunset (H4) for points 2, 7 and 13 as well as E, F and G, dT is around $1 \mathrm{~K}$; for points $3,4,5$ and 14 it is about $2 \mathrm{~K}$; for points $8,9,10$, 11 and 12 as well as point $\mathrm{B}$ around $3 \mathrm{~K}$; for points 6 and $\mathrm{C}$ about $4 \mathrm{~K}$; and for points $\mathrm{A}$ and $\mathrm{D}$ about $5 \mathrm{~K}$. The mean air temperature decrease within the 7-h period in the synoptic station was about $8 \mathrm{~K}$ (Fig. 6). Cloudiness and wind speed are rather low after sunset (less than 1 okta and about $1 \mathrm{~m} \mathrm{~s}^{-1}$, respectively), and the prevailing wind direction is NE, like in type 2 , but the atmospheric calms occur also quite often after sunset (about $20 \%$; Fig. 7). There were 52 nights included in cluster 3 and they were distributed rather evenly in particular months. Like in the case of structure 1, the development of the inversion layer is well seen in data for points $\mathrm{E}, \mathrm{F}$ and $\mathrm{G}$. The height of the inversion layer is similar to that for type 2 (between 160 and $200 \mathrm{~m}$ a.g.l.; Fig. 8). Points 2 and 7 located in the city centre (representing the UHI peak zone) show the lowest values of differences (about $1 \mathrm{~K}$ ). The next group of points, representing areas with blocks of flats and residential built-up districts in the valley floor (points 3, $4,5)$ is characterized with the difference values close to $2 \mathrm{~K}$ during most of the night-time and can be regarded as the UHI plateau zone. The third group of points $(8,9,10,11$ and 12) can be distinguished to represent the UHI slope zone, with the differences reaching $3 \mathrm{~K}$. Those are points representing urban green and water areas in the valley floor and residential built-up areas on the slopes. Points representing rural areas in the valley floor and $70 \mathrm{~m}$ above it (points $\mathrm{A}$ and $\mathrm{D}$ ) are characterized by the same relative rate of cooling, but difference values reach $5 \mathrm{~K}$, showing the cold air lake formation. Like in the case of structure 2, blocks of flats located on the slopes cannot be easily included in any classic UHI zones.

4. Structure type (cluster) 4-the atmospheric features which significantly distinguish type 4 from the other types are the highest relative humidity (Fig. 6), the highest mean shares of SW and $\mathrm{W}$ wind directions in particular hours (Fig. 7) and the largest height of the inversion layer (about $220 \mathrm{~m}$ a.g.1.; Fig. 8). There were 49 nights included in cluster 4 , and, like in the case of cluster 3 , they were distributed rather evenly throughout the year. In the fourth hour after sunset (H4), averaged air temperature at points 2,13 and 14 is similar to the value at point 1 ; for points 3 , 4, 5, 7, 9 and 10 as well as $\mathrm{E}$ and $\mathrm{F}$, dT is around $1 \mathrm{~K}$; for points 6,11 and 12 as well as points $\mathrm{C}$ and $\mathrm{G}$ it is about $2 \mathrm{~K}$; for points 8 and $\mathrm{B}$ around $3 \mathrm{~K}$; and for points $\mathrm{A}$ and $\mathrm{D}$ about $4 \mathrm{~K}$. The identification of the classic UHI zones is complicated again, as in the case of structure 3. However, some features observed earlier may be seen. The largest differences (about $4 \mathrm{~K}$ ) are observed for points $\mathrm{A}$ and $\mathrm{D}$, as usual indicating the formation of the cold air reservoir. Almost all urban points located in the valley floor could be included in the peak zone; however, a difference between the eastern and western parts of the valley can be seen; and larger difference values are observed in the eastern one. Inversion layer formation is visible mainly in the data for points $\mathrm{E}$ and $\mathrm{F}$. The UHI plateau zone could be defined as green areas in the valley floor and residential built-up areas on the slopes (points $6,8,11,12$ ), but very slight difference values in the case of areas with blocks of flats on the slopes can hardly be interpreted as the UHI peak zone continuation.

In all four structures distinguished, the following elements can be seen: inversion layer, cold air reservoir, UHI peak zone and UHI plateau zone. Table 4 shows some further details as a summary of the above structure descriptions.

\section{Discussion}

The spatial and temporal structure types of air temperature differences, presented in the previous section, were distinguished using data only for the nights with low cloudiness and wind speed. However, the comparison of structures 1 and 2 shows that even the increase in wind speed to $2.5 \mathrm{~m} \mathrm{~s}^{-1}$ changes the spatial pattern of air temperature differences significantly, while mean cloudiness was almost the same for all structure types. A similar pattern was described for Lisbon (Alcoforado and Andrade 2006). During calm nights, the air temperature at the hilltops surrounding the city was higher than in the city centre, due to inversion formation and katabatic flows, while during windy nights, the pattern 
Table 4 Selected characteristic features of the air temperature difference structures distinguished

\begin{tabular}{lllll}
\hline Characteristics & \multicolumn{2}{l}{ Structure (cluster) } & & \\
\cline { 2 - 5 } & 1 & 2 & 3 & 4 \\
\hline Peak UHI zone & $1,2,5,7$ & $1,2,3,4,5,6,7,13$ & $1,2,7$ & $1,2,3,4,5,7,9,10$ \\
Plateau UHI zone & $3,4,13,14$ & $8,9,10$ & $3,4,5$ & $6,8,11,12$ \\
Special feature & Highest difference values & Lowest difference values & Transitional structure & $\begin{array}{l}\text { Transitional structure; the eastern } \\
\text { part of the city warmer than the western one }\end{array}$
\end{tabular}

was the opposite. Another factor which has an impact on the differences in spatial pattern is connected with the relief impact and it is the height of the inversion layer; the largest difference values (structure 1) were observed when the inversion layer was the lowest. When the inversion layer was the highest (structure 4), it was also noticed that the wind directions W and SW prevailed and the UHI peak zone had the largest spatial extent. So far, there are no studies on the connection between the inversion layer height and wind direction in Kraków, and studies on the connection between the atmospheric circulation and air pollution, including the role of the inversion layer, provide only the information that during the occurrence of atmospheric circulation types with the advection from south or west (according to the Litynski classification), the height of the inversion layer increases, which indirectly supports the results presented above (Godłowska and Tomaszewska 2010).

Particular measurement points belong to various types of LCZ (Table 2). However, the application of the classic UHI approach seems to be inefficient, i.e. the connection between LCZ and UHI intensity is not clear cut in this case with additional relief effects. Points representing, for example, dominating LCZ 4 (nos. 3, 13, 14) are assigned to different UHI zones in particular structure types (Table 4). Moreover, at rural points, changes in air temperature differences are in some cases similar to those in urban points (Fig. 4). There are, however, three permanent elements which can be found in all structure types and also in Fig. 4; these are the points where the air temperature difference courses always show the formation of the following:

1. The inversion layer: points $\mathrm{E}, \mathrm{F}$ and $\mathrm{G}$

2. The cold air reservoir: points $A$ and $D$

3. The UHI peak zone: point 2 and 7

The results presented above show that some measurement points located in the same LCZ (Fig. 4) show different types of air temperature difference changes during the night-time, depending on their orography location (Fig. 2). It can be concluded that in the inner part of the urban area, the orographydriven phenomena have little impact on air temperature courses, but the suburbs can be affected significantly. In the case of inner parts of urban areas, the increased roughness is a strong barrier for the katabatic flows, so their impact is rather limited. As shown e.g. by Kuttler et al. (1996) or Nkemdirim (1980), in case of cities located in narrow, mountain valley, during clear and calm nights, the cold air that reaches a city with katabatic flows is first blocked and high air temperature differences between urban and rural areas are observed. However, later in the night, the cold air enters a city interior and the differences decrease. That is not the case in Kraków where large differences in the valley floor are observed until sunrise. Air temperature difference changes in the areas with urban built-up land use located in the valley floor always show the features characteristic for urban areas, while areas with urban built-up land use located on the slopes sometimes experience conditions similar to those occurring in rural areas (Figs. 4 and 5). It means that in the suburban zone, at the slopes, the katabatic flows enter the built-up areas occasional1y. The comparison of data presented in Table 2, Fig. 2 and Section 4.2 shows that the impact of topographic and land use/ land cover factors on night-time air temperature changes is modified by the influence of local climate features to a large extent. For example, rural points at the hilltops like E, F or G can experience air temperatures almost as high as those in urban areas with dense built-up land use, while other rural areas with similar land use/land cover features (A and D) are about $6 \mathrm{~K}$ colder than the city centre. As already mentioned in the previous section, in the description of structure type 1, the relief of the study area is diversified in both N-S and W-E cross-sections which is the reason for the larger intensity of katabatic flow effects in the western part of the city than in the eastern part. The large diversity of thermal conditions in the rural areas around Kraków was also observed for the day time land surface temperature obtained from Landsat satellite data (Walawender et al. 2014).

In the case of cities like Kraków, the application of the traditional UHI intensity concept is problematic. The core assumption of the UHI intensity is the air temperature increase in urban areas due only to land use/land cover changes and impact. Urban areas belonging to various LCZs are compared with one rural reference point. The first issue to be discussed is the determination of stations which should be compared to obtain urban-rural air temperature difference. The well- 
known UHI concept has already been questioned, e.g. in relation to the cold front passages (Szymanowski 2005) or particular land use conditions (Stewart 2011b). In the present study, the impact of relief parallel to the land use/land cover impact is the factor to be considered. It is relatively easy to identify in Kraków the urban core area, located in the valley floor, with the highest air temperature. However, the rural surroundings are highly diversified in terms of thermal conditions, from the cold air reservoir to areas located above the inversion layer; even the rural areas in the valley floor are quite diversified, with clear differences between the very cold western part and the much warmer eastern part. Therefore, it is proposed to define UHI and its intensity in the context of the whole thermal structure presented above. That task can be realized in two steps.

First, the analyses presented above suggest that it is not possible to separate the influence of relief from the land use/ land cover impact on air temperature in particular parts of the city and the valley. The results obtained show that measurement points located in similar relief conditions or in similar land use/land cover conditions can belong to one cluster or be included in different clusters. Additionally, the situation changes with relatively small change in meteorological conditions, which can be interpreted as an interruption of the impact of land use/land cover factors that are usually rather stable during calm, cloudless nights. It is a complicated process, generated by the interaction between relief and land use/land cover. Thus, we have to reject the hypothesis that these two thermal signals can be separated. And therefore, we introduce a concept of a reliefmodified urban heat island (RMUHI). It consists of two steps: (1) recognition of the areal thermal structure taking into consideration the city centre as a reference point and (2) calculation of RMUHI intensity separately for each vertical zone.

Following the already-mentioned concept of Lowry (1977), air temperature in various parts of a city located in a valley is a result of large-scale weather conditions modified by a combined impact of the land use and relief. Rural stations are located in different thermal conditions, so none of them can be chosen as a reference point. That is why the reference point should be the city centre, representing the RMUHI peak zone. That approach allows the whole thermal structure of the study area to be seen. However, a methodological problem of RMUHI intensity arises. As mentioned above, in the classic UHI approach, the UHI intensity is defined for each urban LCZ separately, by calculating the air temperature differences between the rural reference station and a certain urban station. In the case of RMUHI, data from all urban measurement points are compared with the city centre, i.e. also an urban point. RMUHI intensity for that part of the valley where the city centre is located (in the case of Kraków, it is the valley floor) can be defined as the difference between the city centre and a rural point located in the same landform. However, in the case of the parts of the city located in other landforms, the second step of the procedure can be proposed.

The analyses shown in previous sections show that rural stations present various patterns of air temperature differences. Additionally, the maximum value of the differences varies a great deal among the rural stations. That is the effect of the processes forced by the presence of the diversified relief, e.g. katabatic flows or inversion layer formation. Those processes can only partially be traced in the air temperature patterns for urban points, most probably because of the increase in roughness mentioned above and also because most urban areas are not affected by the lifted inversion layer, often forming above the urban canopy layer. The urban structure shows a large inertia, and the local mesoclimatic phenomena can modify the air temperature significantly only in the suburbs. However, the extent of the modification depends on weather conditions. According to the goal of the paper described in Section 1, the results presented show that it is not possible to clearly separate the impact of the relief from the impact of the land use/land cover. Still, it seems reasonable to propose the definition of RMUHI intensity to be established separately for the vertical zones, i.e. urban stations from particular zones should be compared with rural stations from the same zones. Such approach is in accordance with the solutions proposed by Goldreich $(1984,2009)$ who suggested to establish UHI intensity in cities with diversified relief using urban and rural stations located at similar altitude and height above the valley floor. However, a few important assumptions have to be highlighted. In each vertical zone, there are different local climatic processes affecting the air temperature in rural and urban areas. Air temperature in urban and rural areas in a particular vertical zone is not affected in the same way by those processes. Therefore, the RMUHI intensity should be established separately for each particular vertical zone, but it is not recommended to compare such magnitudes between the zones, for the same land use/land cover types. For example, in Kraków, there are urban areas with blocks of flats located in the valley floor and on a slope. In order to calculate the intensity of RMUHI, the area with blocks of flats in the valley floor will be compared with the area of a cold air lake while the other one with an area experiencing katabatic flow. Additionally, the first urban area mentioned above is not affected by the local mesoclimatic processes while the other one might be affected by those processes depending on weather conditions.

\section{Conclusion}

In the case of Kraków, a city located in a large valley, outside mountain areas, the application of the LCZ and UHI concept 
is problematic, due to the significant impact of relief-induced mesoclimatic processes on the thermal structure of the study area. Therefore, the paper introduces a modification of the classic approach to UHI definition. The concept of RMUHI (i.e. relief-modified UHI) is proposed as an alternative solution. The RMUHI concept focuses mainly on UHI calculation assumptions, following Lowry's model as mentioned above showing the common impact of relief and land use/land cover. Concerning the RMUHI concept, UHI is first presented as an element of a complex thermal structure influenced by land use/land cover, topographic features and local climate processes forced by the presence of a diversified relief. To show that complex thermal structure first, the city centre is taken for the reference point, as it is the only point which always belongs to the same element of the thermal structure within the whole study area, i.e. to the area where the air temperature is the highest during the night-time. Rural areas surrounding Kraków are highly diversified in terms of thermal conditions, due to the influence of the cold air lake and inversion layer formation, and katabatic flows. Hence, it is not possible to choose one rural measurement point as a reference point. Additionally, the thermal structure is sensitive to the relatively small changes in weather conditions, e.g. the increase in the wind speed up to $2.5 \mathrm{~m} \mathrm{~s}^{-1}$. Following the above reasoning, in the second step, the magnitude of RMUHI in Kraków can be defined as a set of maximum values in night-time mean air temperature difference courses, calculated separately for the two vertical zones in which built-up areas are located and for the four types of the RMUHI structure types distinguished. In each case, the difference concerns a rural station located in a certain vertical zone and an urban station representative for a certain LULC:

\section{Valley floor}

(a) Dense urban built-up areas in the city centre (air temperature difference between points 1 and A): from $6.6 \mathrm{~K}$ (structure type 1) to $3.6 \mathrm{~K}$ (structure type 2)

(b) Blocks of flats (points 3 and A): from $3.7 \mathrm{~K}$ (structure type 1 ) to $2.5 \mathrm{~K}$ (structure type 4 )

(c) Residential built-up areas (points 5 and A): from $4.1 \mathrm{~K}$ (structure type 1 ) to $2.4 \mathrm{~K}$ (structure type 2 )

(d) Urban green areas (points 6 and A): from $2.7 \mathrm{~K}$ (structure type 3 ) to $2.3 \mathrm{~K}$ (structure type 4)

2. North slopes $50 \mathrm{~m}$ above the valley floor

(a) Residential built-up areas (points 11 and B): from $1.4 \mathrm{~K}$ (structure type 1) to $0.8 \mathrm{~K}$ (structure type 3)

3. South slopes $50 \mathrm{~m}$ above the valley floor

(a) Blocks of flats (points 13 and $\mathrm{C}$ ): from $2.6 \mathrm{~K}$ (structure type 1 ) to $1.7 \mathrm{~K}$ (structure type 4 ) (b) Residential built-up areas (points 12 and C): from $1.5 \mathrm{~K}$ (structure type 1 ) to $0.6 \mathrm{~K}$ (structure type 4 )

The values presented above should be interpreted taking into consideration the particularities of the study area, i.e. values mentioned in point 1 (a) show the air temperature difference between the city centre and the cold air reservoir.

The RMUHI concept can be used in other cities where the relief is not only diversified but also generates mesoclimatic processes which have a significant impact on air temperature not only in the urbanized area itself but also in surrounding rural areas. The procedure described in this paper can be regarded as an initial phase in elaborating a spatially continuous thermal structure in the urban area, but the mobile measurements of air temperature profile across the city of Kraków conducted so far (Bokwa 2010) indicated that no simple modelling approach could be used.

Open Access This article is distributed under the terms of the Creative Commons Attribution 4.0 International License (http:// creativecommons.org/licenses/by/4.0/), which permits unrestricted use, distribution, and reproduction in any medium, provided you give appropriate credit to the original author(s) and the source, provide a link to the Creative Commons license, and indicate if changes were made.

\section{References}

Alcoforado MJ, Andrade H (2006) Nocturnal urban heat island in Lisbon (Portugal): main features and modelling attempts. Theor Appl Climatol 84:151-159

Błażejczyk K, Kuchcik M, Milewski P, Dudek W, Kręcisz B, Błażejczyk A, Szmyd J, Degórska B, Pałczyński C (2014) Urban heat island in Warsaw. Climatic and urbanistic factors (Miejska wyspa ciepła w Warszawie. Uwarunkowania klimatyczne i urbanistyczne). Wydawnictwo Akademickie Sedno, Warszawa.

Bohnenstengel SI, Evans S, Clark PA, Belcher SE (2011) Simulations of the London urban heat island. Q J R Meteorol Soc 137:1625-1640

Bokwa A (2010) Multi-annual changes of the urban mesoclimate structure using an example of Kraków (Wieloletnie zmiany struktury mezoklimatu miasta na przykładzie Krakowa). Institute of Geography and Spatial Management. Jagiellonian University, Kraków

Camilloni I, Barrucand M (2012) Temporal variability of the Buenos Aires, Argentina, urban heat island. Theor Appl Climatol 107:47-58

Erell E, Williamson T (2007) Intra-urban differences in canopy layer air temperature at a mid-latitude city. Int J Climatol 27:1243-1255

Everitt BS, Landau S, Leese M (2001) Cluster analysis, 4th edn. Oxford University Press Inc, New York, Arnold, London

Fortuniak K, Kłysik K (1998) The model of winter night-time temperature distribution in Lodz. Acta Univ Lodz. Folia Geogr-Phys 3:393401

Fortuniak K, Kłysik K (2008) Singularities of urban climate— Lódź case study (Osobliwosci klimatu miast na przykladzie Lodzi). In: Klysik K, Wibig J, Fortuniak K (eds) Climate and bioclimate of cities (Klimat i bioklimat miast). Wyd Uniw Łódzkiego, Łódź, pp. $477-$ 488 
GMES-Mapping Guide for a European Urban Atlas v. 1.01 (2010) available on-line: www.eea.europa.eu Accessed 01-06-2014.

Godłowska J, Tomaszewska AM (2010) Relations between circulation and winter air pollution in Polish urban areas. Arch Envir Prot 36: $55-66$

Goldreich Y (1984) Urban topoclimatology. Prog Phys Geogr 8(3):336-364

Goldreich Y (2009) Updating the urban topoclimatology - a review. In: Mat 7th Int Conf on Urban Climate, Yokohama, Japan, pp. 29.0623.072009

Hage KD (1972) Nocturnal temperatures in Edmonton, Alberta. J Appl Meteorol 11:123-129

Hess M (1974) Climate of Krakow (Klimat Krakowa). Folia Geogr ser Geogr-Phys 8:45-102

Hočevar A, Petkovšek Z (1995) Some climatic peculiarities of towns and their changes in basins of temperate climate belt. In: Kłysik K (ed) Climate and bioclimate of cities (Klimat i bioklimat miast). Wyd Uniw Łódzkiego, Łódź, pp. 21-30

Holmer B, Thorsson S, Eliasson I (2007) Cooling rates, sky view factors and the development of intra-urban air temperature differences. Geogr Ann 89A(4):237-248

Jauregui E, Godinez L, Cruz F (1992) Aspects of heat-island development in Guadalajara, Mexico. Atmos Environ 28B:391-396

Ketterer C, Matzarakis A (2014) Human-biometeorological assessment of the urban heat island in a city with complex topography - the case of Stuttgart, Germany. Urban Climate. doi: 10.1016/j.uclim.2014. 01.003

Ketzler G, Schneider C, Havlik D, Peschel G (2006), Analysis of urban climate and detection of urban climate change in the city of Aachen over a 30-year period - temperature variation and trends in complex terrain. $6^{\text {th }}$ Int Conf on Urban Climate, Goteborg, Sweden, 12 16.06.2006, IAUC, WMO, Goteborg Univ., pp 685-688.

Kuttler W, Barlag A-B, Rossmann F (1996) Study of the thermal structure of a town in a narrow valley. Atmos Environ 30:365-378

Lazar R, Podesser A (1999) An urban climate analysis of Graz and its significance for urban planning in the tributary valleys east of Graz (Austria). Atmos Environ 33:4195-4209

Lewińska J, Bartosik J, Baścik J, Czerwieniec M, Zgud K (1982) Impact of urban area on local climate (with Krakow agglomeration as an example) (Wpływ miasta na klimat lokalny (na przykładzie aglomeracji krakowskiej)). Inst Kształt Środ, Warszawa

Lowry WP (1977) Empirical estimation of urban effects on climate: a problem analysis. J Appl Meteorol 16:129-135

Mydel R (1996) Territorial expansion and evolution of the spatial structure of the city of Kraków in the period 1946-1990 (Terytorialny wzrost i ewolucja struktury przestrzennej miasta Krakowa w okresie 1946-1990). Folia Geogr ser Geogr-Oecon 27-28:279-295

Nkemdirim LC (1980) Cold air drainage and temperature fields in an urban environment: a case study of topographical influence on climate. Atmos Environ 14:375-381

Oke TR (1987) Boundary layer climates. Methuen, London

Oke TR (2004) Initial guidance to obtain representative meteorological observations at urban sites. IOM Report 81, World Meteorological Organization, Geneva.

Panek T (2009) Statistical methods of multi-dimension comparative analysis (Statystyczne metody wielowymiarowej analizy porównawczej). SGH Warszawa

Roten M, Ruffieux D, Fallot J-M (1984) Research on the climate of Fribourg (Switzerland), a city of 50000 with unusual topographic conditions. Energy Build 7:117-137

Rupnik G (2003) Environmental and climate studies in Salzburg (Umweltklimatologische studie Salzburg). Salzburger Geographische Arbeiten 37.
Rzepa M, Gromek B (2009) Annual variability of SVF in the centre of the Łódź city (Zmienność roczna współczynnika widoku nieba w centrum Łodzi). Prace Geograficzne IGiGP UJ 122:63-70

Saaroni H, Ziv B (2010) Estimating the urban heat island contribution to urban and rural air temperature differences over complex terrain: application to an arid city. J Appl Meteorol Climatol 49:2159 2166 doi: http://dx.doi.org/10.1175/2010JAMC2473.1

Stewart ID (2009) Classifying urban climate field sites by "Local Climate Zones". Urban Climate News 34(4):8-11

Stewart ID (2011a) Redefining the urban heat island. PhD dissertation, University of British Columbia, Department of Geography pp 352 https://circle.ubc.ca/handle/2429/38069. Accessed 01.10.2014.

Stewart ID (2011b) A systematic review and scientific critique of methodology in modern urban heat island literature. Int J Climatol 31: 200-217

Stewart ID, Oke TR (2009) Classifying urban climate field sites by local climate zones: the case of Nagano, Japan. Preprints, Seventh Int. Conf. on Urban Climate, Yokohama, Japan, Int. Assoc. Urban Climate. http://www.ide.titech.ac.jp/ icuc7/extended abstracts/pdf/ 385055-1-090515165722-002.pdf

Stewart ID, Oke TR (2012) Local climate zones for urban temperature studies. Bull Am Meteorol Soc 93:1879-1900. doi:10.1175/BAMSD-11-00019.1

Suomi J, Käyhkö J (2012) The impact of environmental factors on urban temperature variability in the coastal city of Turku, SW Finland. Int J Climatol 32(3):451-463

Szymanowski M (2004) Urban heat island in Wroclaw (Miejska wyspa ciepla we Wroclawiu). In: Studia Geograficzne 77, Acta Universitatis Wratislaviensis 2690. Wydawnictwo Uniwersytetu Wroclawskiego, Wroclaw

Szymanowski M (2005) Interactions between thermal advection in frontal zones and the urban heat island of Wroclaw Poland. Theor Appl Clim 82:207-224

Walawender JP, Szymanowski M, Hajto MJ, Bokwa A (2014) Land surface temperature patterns in the urban agglomeration of Krakow (Poland) derived from Landsat-7/ETM+ data. Pure Appl Geophys 171:913-940. doi:10.1007/s00024-013-0685-7

Walczewski J (1989) Development of SODAR and acoustic soundings of the atmosphere in Poland. Z Meteorol 39(3):129-141

Walczewski J (ed) (1994) Characteristics of the atmospheric boundary layer over an urban area - the case of Cracow (Charakterystyka warstwy granicznej atmosfery nad miastem (na przykładzie Krakowa)), Materiały badawcze, ser. Meteorologia, 22, IMGW, Warszawa.

Walczewski J, Feleksy-Bielak M (1988) Diurnal variation of characteristic sodar echoes and the diurnal change of atmospheric stability. Atmos Environ 22(9):1793-1800

Wanner H, Hertig J-A (1984) Studies of urban climates and air pollution in Switzerland. J Clim Appl Meteorol 23:1614-1625

Zborowski A (2005)Changes of social-spatial structure of an urbanized region during the time of real socialism and system transformation (with Kraków as an example) (Przemiany struktury społecznoprzestrzennej regionu miejskiego $\mathrm{w}$ okresie realnego socjalizmu i transformacji ustrojowej (na przykładzie Krakowa)). Institute of Geography and Spatial Management, Jagiellonian University, Kraków.

Zimnoch M, Godlowska J, Necki JM, Rozanski K (2010) Assessing surface fluxes of $\mathrm{CO}_{2}$ and $\mathrm{CH}_{4}$ in urban environment: a reconnaissance study in Krakow, southern Poland. Tellus B 62(5):573-580 